\title{
Toward Successful Bank-Fintech Partnerships: Perspectives from Service Providers in an Emerging Economy
}

\author{
Yen H. Hoang ${ }^{1}$, Nhung T. H. Nguyen ${ }^{1}$, Ngoc B. Vu ${ }^{2}$, Duong T.T. Nguyen ${ }^{1} \&$ Linh H.T. Tran ${ }^{2}$ \\ ${ }^{1}$ School of Banking, University of Economics Ho Chi Minh City, Vietnam \\ ${ }^{2}$ Ho Chi Minh City Open University, Vietnam \\ Correspondence: Ngoc B. Vu, School of Advanced Studies, Ho Chi Minh City Open University, Vietnam. E-mail: \\ ngoc.vb@ou.edu.vn
}

Received: April 11, 2021

doi:10.5539/ass.v17n6p19
Accepted: April 29, $2021 \quad$ Online Published: May 31, 2021

URL: https://doi.org/10.5539/ass.v17n6p19

\begin{abstract}
Banks and Fintech companies view each other as partners rather than competitors because of the potential benefits they can gain from each other in the cooperation process. In that process, the perspectives of each party are very likely to determine the outcome of the cooperation. This study is conducted to examine the perspectives of banks and fintech companies in the collaboration process, hence, identify factors that can potentially affect the success of a bank-fintech partnership. A qualitative methodology was adopted, including in-depth interviews and focus group discussion with two groups of commercial banks and fintech companies conducted in Vietnam in 2019. The study findings include the benefits, the obstacles, advantages and disadvantages of each party as well as their strengths and weaknesses, partner selection criteria are among important factors that can influence the cooperation process. Obtained findings imply important policies to ensure successful partnerships between banks and fintech in Vietnam.
\end{abstract}

Keywords: banks, co-operation, digital banking, fintech, bank-fintech partnership, emerging economy

\section{Introduction}

In the recent years, Vietnam's fintech industry has grown significantly thanks to the increasing adoption of digital transactions, the development of e-commerce, and the government's policies to enhance digital payments (Di Rosa, 2020). In 2019, Vietnam ranked the second in ASEAN in fintech financing, attracting $36 \%$ of the total investment in fintech of the region (only behind Singapore with 51\%), as foreign investors are always optimistic about the potential of fintech in Vietnam. This optimism is reinforced in the context of controlling the spread of COVID-19 epidemic in Vietnam leading to the eruption of digital payments and e-commerce activities. In the first quarter of 2020, electronic payment increased $76 \%$ with the total transaction value increased $124 \%$ compared to Q1 2019 (Di Rosa, 2020), which is an unprecedented growth rate up to present.

This outcome is succesfully achieved thanks to government policies in promoting cashless payments, digital banking and green banking, which are the top three priorities for the industry in the period 2020-2025 (Statebank, 2019). Currently, Fintech companies operate in a veriaty of areas, however, payment are still the dominant segment in which 30\% of fintech companies operating in and attracted $98 \%$ of total investments in Fintech in Vietnam in 2019 ( PWC, 2019). The reason for this significant investment in the payment sector of fintech is the business potential of a market with a large population (97.4 million people) while the number of bank accounts are still limited (30.8\%) and but the proportion of population using Internet and mobile devices are quite high (57\% and 47\%, respectively) (Nielsen Vietnam, 2020).

In 2015, Vietnam had 39 fintech startups, mainly in the payment sector. By 2019, this figure tripled to 124 fintech companies, covering a broad range of services that include digital payments, alternative finance, wealth management and blockchain. With their distinct advantages in technology, fintech companies have become competitors of traditional commercial banks in providing a number of banking and financial services such as digital lending services, mobile money transfer services (Francis, Blumenstock, \& Robinson, 2017). Specifically, $83 \%$ of traditional financial institutions are concerned that part of their business is at risk of being lost to Fintech (PWC, 2016). Within 5 years (2016-2021), 24\% market share of banks in remittance and payment is estimated to be transferred to Fintech companies, this figure is $22 \%$ in the field of asset management and $21 \%$ in the 
insurance sector (PWC, 2016). However, as a matter of fact, the development of Fintech in the recent years has brought positive change to Vietnam's economy. Vietnamese banks have accelerated their digital push, partnering with Fintech companies to ramp up efforts. For example, Vietnam's Tien Phong Commercial Joint Stock Bank (TPBank) recently partnered with digital banking platform Backbase to provide its customers with digital priority products and services. Non-cash payments, digital banking and green banking are the top three priorities of the industry in the period 2020-2025 in Vietnam. Besides, the development of digital banking is accelerating the combination of Fintech rapidly, the e-commerce industry is booming. Although many banks have chosen to cooperate with foreign fintechs, such as VietinBank and Opportunity Network (UK), CIMB Bank Vietnam and Toss (Korea), VPBank and BE Group (Sweden), OCB and RippleNet (USA), TPBank and Backbase (Netherlands), several other banks have partnered with local startups.

Research by Chanaka Jayawardhena, Paul Foley, (2000) shows how competitive the services provided by 4000 financial companies compared with traditional products and banking electronic services. However, it cannot be denied the fact that traditional commercial banks still have their own strengths that Fintech companies do not have. Specifically, Fintech companies, despite having digital technology, have not built customers' confidence in security and safety as well as lacking a large customer network compared to traditional banks (Marous, 2016). Furthermore, even though the biggest disruptive potential of Fintech lies in payments systems, the possibility that P2P lending applications of fintech can replace banks depends on the capital constraints of banks (Thakor, 2020). In addition, competition is likely to force banks "to be more efficient, perhaps reducing their propensity to overlend and engage in evergreening" (Thakor, 2020).

Recognizing the importance of technology, many banks have now cooperated with Fintech companies to initiate, install and develop fintech-banking services (Mocker et al., 2015). Since then, banks and Fintech companies view each other as partners rather than competitors (Mocker et al., 2015) because of the potential benefits they can gain from each other in the cooperation process. In addition, studies on the preparation stage for comprehensive cooperation between banks and Fintech companies include research by Pavlou, P. A., \& Gefen, D., 2004); Pavlou, P. A., Liang, H., \& Xue, Y., (2007); Ng et al. (2017).

These studies largely define the advantages of each party, banks and Fintech companies in the process of cooperating to provide Fintech - banking products, as well as the intention to use fintech products and the level of customer satisfaction. These studies focus on individual issues of digital banking or fintech. There has not been a comprehensive qualitative study on the banking-fintech relationship, advantages and disadvantages in the cooperation process, partner selection criteria, as well as the prospects of the products developed from the collaboration of these two entities.

Based on the development of fintech companies and the prospect of cooperating with banks in many areas of digital banking, this study is conducted to examine the perspectives of banks and fintech companies in the collaboration process. A qualitative methodology was adopted for the study. In-depth interviews and focus group discussion with two groups of commercial banks and fintech companies were conducted in Vietnam in 2019. The reseach findings include the impacts and benefits of cooperation between banks and fintech companies and several related issues such as the obstacles, advantages, strengths and weaknesses, criteria and products during their cooperation progress.

The research findings provide Fintech companies and banks with a comprehensive scientific basis of their expectations as well as their partners to make the right decisions and strategies for the cooperation process between banks and Fintech companies. The study also suggests policy makers in making appropriate legal provisions to promote the development of the Fintech - banks cooperation.

The remainder of the paper is structured as follows. Section 2, reviews the related literature on the relationship between commercial banks and fintech companies. Section 3 describes the data and methodology. Section 4 reports the findings of the research, and section 5 concludes the paper, suggesting various policy implications.

\section{Literature Review}

\subsection{Cooperation Theory for Organizations}

Cooperation is defined as a process by which two or more firms that work together or act together for the mutual benefit in the long-term (Rotering, 1993). In fact, there are many different types of cooperation of which alliance is one typical form. Gulati (1998) describes alliances as a mutual arrangement between independent companies to share and exchange resources as they are unable to create all the necessary resources on their own (Child, 1974; Pfeffer \& Salancik, 1978). Resource sharing, for example, might include co-developing or providing products, services, and technology. The alliance has specific objectives, is negotiated and then all involving 
parties commit to implementation (Dushnitsky, 2008).

Overall, business partners need to invest resources and participate in common projects to form business alliances. In the event of success, all participating partners obtain a share of profit. Especially for young companies, due to the limited financial resources and customer base, they need to cooperate with incumbents that have access to those resources. The survey results of more than 100 start-ups in Gans and Stern (2002) research show a partnership between a start-up and an incumbent (through licensing, alliance or acquisition. acquisition / acquisition) is the preferred approach when the incumbent has resources that are particularly important to that start-up company. In addition, Dushnitsky (2008) outlines the different resources a start-up can have when partnering with an incumbent that has a long track record in the market, which are capital, infrastructure, business know-how, and utilizing the effects of reputation (or endorsement effect). In other words, the collaborative process can create a spillover effect for young companies (Stuart et al., 1999).

Another common form of cooperation is venture capital, which is based on equity investments by different partners in a legal independent entity (Keil, 2000; Maula, 2001; Weber \& Weber, 2007). This form of partnership plays an important role in supporting young companies with high growth expectations and high level of risk. This type of investment pursues two main different goals to maximize the value, including (i) high financial returns and (ii) more diverse and complex innovation objectives (e.g., access to new products, a window on new technologies, or generating demand). In further to this, a formal cooperation allows venture capital funds to provide non-financial supports such as corporate infrastructure, networks or other resources. Hellmann (2002) points out that the success of the new venture sometimes depends significantly on this non-financial support.

\subsection{The Conditions for a Successful Cooperation}

According to Nalebuff et al. (1996), cooperation theory is a model of a strategic framework that allows organizations to classify subjects in a certain industry. This model applies knowledge in game theory to observe and explain different behaviors of economic players. Nalebuff et al. (1996) argue that a process of cooperation and competition exists and is desirable in all industries (Levinson \& Asahi, 1995). On the one hand, when participating in focusing on market growth, players are forced to cooperate to increase the benefits for all parties (Hill \& Lynn, 2003). On the other hand, competition between players will help distribute the benefits gained from each participant depending on their market share. This theoretical framework helps observe how interactions between players and their choices lead to different outcomes or the state of the game at the end. In addition, this theory also helps administrators and researchers to identify and explain the internal mechanisms in the corporate environment, as well as how businesses can influence the mechanisms to serve one's own interests.

\subsection{Cooperation Between Banks and Fintech}

Fintech is an acronym for financial technology. As defined by Ernst \& Young (EY), Fintech are organizations that combine innovative business models and technologies to enhance the efficiency of financial services, while also disrupting and challenging traditional banking business model. Fintech is also considered to be the field that revolutionized financial technology and banking. The Basel Committee on Banking Supervision has accepted the Financial Stability Board (FSB) definition of Fintech, under which Fintech is financial technology innovation that allow the formation of new business models, applications, processes or products that can have a major impact on markets, financial institutions and financial services operations.

With such a broad definition, Fintech is understood as technological innovations carried out by a wide range of stakeholders, from new market entrants to incumbent banks with long-term operations history, from small fintech startups to big tech companies. This definition is also useful in the research and analysis process of the cooperation and competition process between Fintech companies and banks (Navaretti et al., 2018). Overall, Fintech has created a revolution in financial technology, a remarkable improvement in banking services through the provision of new financial solutions as well as digital application models in financial services sector (Puschmann, 2017), thereby helping to optimize the cost structure for the financial industry to meet the needs of consumers.

Along with understanding the benefits that Fintech brings, banks have seen investing in Fintech companies as a way to reduce costs, increase efficiency and improve service quality. Douglas, JL and Grinberg, R (2016) pointed out that the criteria banks are interested in when making investments in Fintech include (i) the legality of operations, (ii) the ability to supervise and manage (iii) the ability of the bank to control the Fintech company in terms of operations and business, (iv) the views of potential investors and their investment structure, and (v) whether regulatory approval is difficult and time-consuming.

According to Chuen (2015), there are five factors that affect the success rate of Fintech: low margin requirement, 
low level of assets, high scalability, high innovation and less complicated compliance process. Furthermore, Haddad and Hornuf (2016) examine the economic and technological factors of Fintech in 69 countries. The research results show that Fintech is forming more in markets where the latest technology is available because young companies need these technologies for their products. This study also shows that Fintech is more likely to be established and develop in countries with weak and fragile financial markets.

Recent publications have also analyzed the relationship between banks and fintechs. Jakšič \& Marinc (2015) point out that Fintech and other information technology companies will create drastic changes in the financial markets due to their innovative products. Similarly, Lacasse et al. (2016) predicts that new services will meet market expectations well and will often deliver a product that outperforms traditional industries. Keith Tiberius and Rasche (2017) show Fintech's disruptive potential by doing a case study, which highlights the advantages of new services in a number of different product segments. Accordingly, PWC (2016) reported that more than 80 percent of interviewees (experts from incumbent financial institutions) believe their business is at risk due to Fintech disruption. Bunea et al. (2016) studied the US Securities and Exchange Commission (SEC) records annually and found evidence that banks consider Fintech a serious threat.

However, other researches have focused on the advantages of cooperation between Fintechs and incumbent banks (Kalmykova, 2016; Burgmaier \& Hüthing, 2015) and discussed different methods of cooperation (Thwaits, 2016; Meinert, 2017). Several similar studies show that collaboration between financial institutions and Fintech is seen as a new opportunity for incumbent banks to gain access to outside innovation (BNY Mellon, 2015; Deutsche Bank Research, 2016). Specifically, Corea (2015) argued that the importance of venture capital funds increased for banks; Bomer and Maxin (2018) conducts a case study on Commerzbank's business incubator, which is the first corporate venture capital organization for Fintechs in Germany. The research results show that regulatory requirements have a large impact on the selection and support process for seven Fintech companies. In addition, Bodek and Matinjan (2017) also conducted a case study on the Comdirect startup project, in which the study focused on the screening, support and innovation goals of the bank.

As such, the two most common reasons for Fintechs to associate with banks is the ability to allow Fintech companies to enter the market and to help Fintechs increase profits. Furthermore, whenever a Fintech needs to cooperate with a bank to enter a market, that Fintech also has an additional goal: either to increase profit or develop new products. In addition, studies show that Fintech in the banking segment often seeks to cooperate with an incumbent bank to take advantage of the customer base, branch network, capital and reputation to increase profits. Meanwhile, by cooperating with Fintech, banks not only can strengthen their competitive advantage thanks to more advanced financial services, but also, in some cases, can achieve the exclusive right to use a specific application or license that allow them to win competitors (Hornuf et al., 2020).

The cooperation process between Fintech and banks is shown in the following chart.

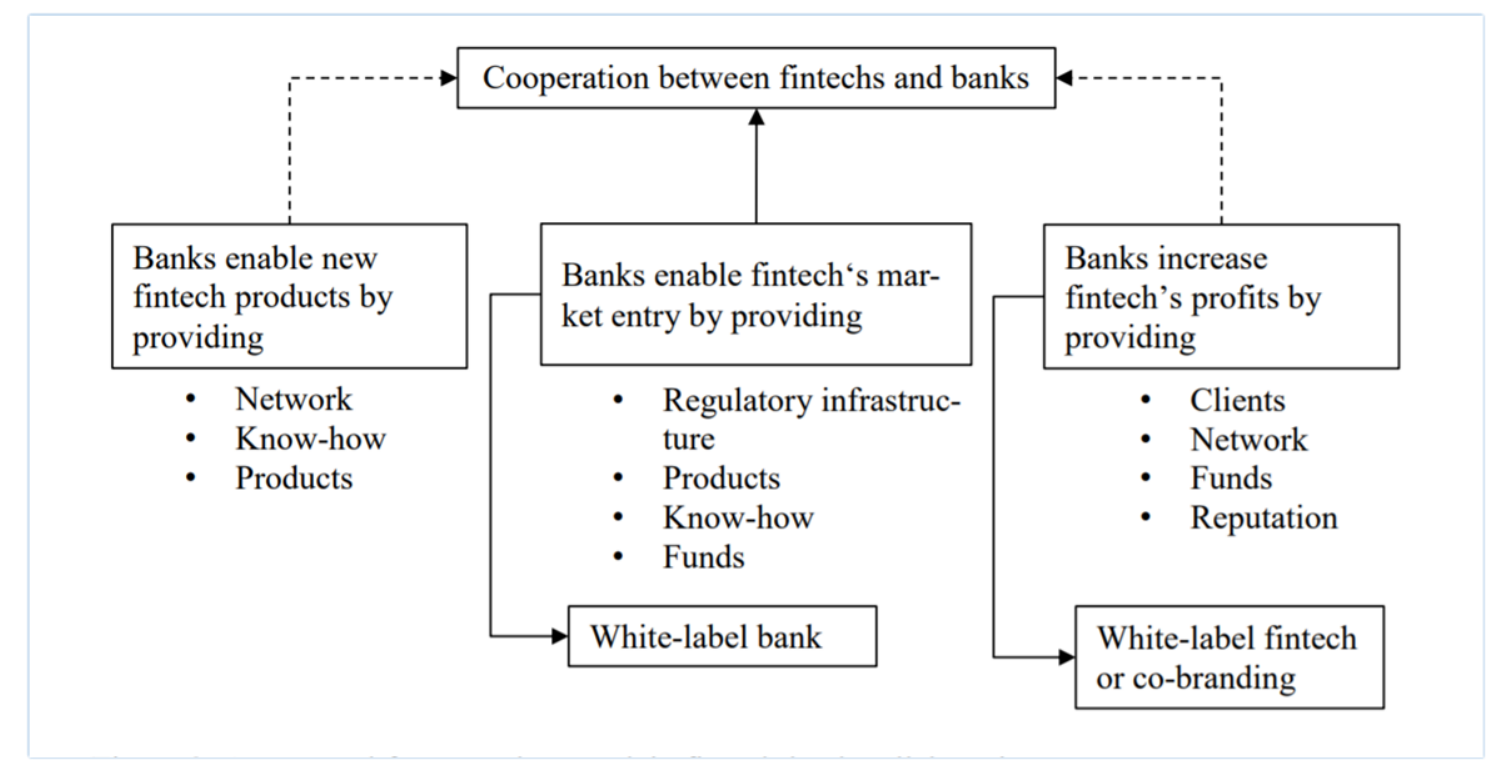

Chart 2.1. The cooperation process between Fintech and banks (Bömer, 2020)

While the above analysis shows the motivations of the cooperative process, the cooperation theory helps to better understand the basis of these motives. Based on the cooperation theory, this study is conducted to determine the 
challenges of fintech integration into banking system in Vietnam, the advantages and disadvantages in the cooperation process, partner selection criteria, as well as the prospects of the products developed from the collaboration of these two entities.

\section{Methodology}

The research was conducted from an interpretive perspective. A qualitative approach using in-depth interviews and focus groups was considered to be appropriate to gain a meaningful understanding of phenomena "which emerge out of sharing and discussing issues, exchanging opinions, revising perceptions and highlighting commonalities and differences" (Carson et al., 2001).

Qualitative research method was used to understand the perspective of the suppliers, fintech companies and banks, regarding to the integration of fintech in banking system.

Regarding commercial banks, the stratified sampling method according to two groups of Vietnamese banks is implemented, including: Group 1 is the joint stock commercial banks with more than 50\% State ownership (coded as SCB), group 2 is other commercial banks (coded as CB). Group 1 includes one bank with the largest market value among Vietnamese banks while group 2 also includes other banks with considerable market share in banking sector.

In regards of fintech companies in Vietnam, Group 1 is fintech companies that have been established and operated for more than 3 years (coded as Fintech 1). Group 2 is fintech companies established and operating for less than 3 years (coded as Fintech 2). Fintech companies in the group 1 and 2 are either from multi-national corporations or leading technology companies in Vietnam.

After stratifying into groups of banks and Fintech companies, the sampling balanced stratification method was applied to select each group of 3-5 banks/ fintech companies, representing each group to participate in the interview. These groups were selected according to the criteria of similar in size, business activity and target customers.

In-depth interviews and focus group discussion with product managers, retail banking directors, managing directors of banks/ fintech companies to assess the background of $\mathrm{x}$ fintech integration in banking system.

Grounded theory, which grew from the work of Glaser and Strauss (1967), is an inductive approach to qualitative research. In-depth interviews and focus group discussion were used to identify patterns emerging from the data and seek to identify a theoretical framework from these, rather than forming hypotheses from existing theory and then testing these using the findings (De Chernatony \& Cottam (2006). Qualitative data was collected from in-depth interviews with a topic guide. The issues addressed are the responses to several topics, in which respondents were asked about the impacts and benefits of cooperation between banks and fintech companies; the obstacles they face when implementing the cooperation, the bank's criteria when choosing cooperation partners and vice versa; their strength/ weakness in cooperation progress; the banking product types have been cooperated and will be integrated in the future.

\section{Findings and Discussion}

\subsection{The Benefits of the Cooperation Between Banks and Fintech Companies}

When asked if banks are concerned about the risk of their market share being lost due to Fintech competition, most banks say they are concerned about that problem, but not to a large extent. According to the most common opinion, banks have advantages over Fintech in terms of customer networks, size and reputation and are now investing heavily in e-banking services. On the other hand, SCB has important customer segments such as large enterprises and traditional banking customers, which are competitive advantages that is difficult for Fintech to access. Regarding the change in banking products with the development of Fintech, most of the interviewed banks (SCB and CB) said that their products were, are and will change a lot compared to other banks, especially for traditional products, especially deposit or payment products. Currently all banks provide electronic banking services and connect payment gateways with Fintech companies in the payment field.

Regarding the change of the bank's management structure in the process of competition - cooperation with Fintech, SCB commented that there is a change in the management structure as well as some technology software needs to be integrated for banks and Fintech, leading to changes in personnel and management structure.

Results of interviews with banks about the benefits when cooperating with Fintech, most of the banks (SCB and CB) said that cooperation helps banks promote financial inclusion, helps reduce costs, increase revenue, innovate new products and therefore, increase the number of customers. Particularly, SCB said that the cooperation 
motivated the bank to restructure, streamline staff and innovate internal management.

Results of interviews with representatives of FT1 and FT2 about the benefits of working with the bank show that the cooperation helps fintech increase brand awareness; increase customer confidence; access to capital (eg payment via e-wallets, receiving bank's investment capital....); Take advantage of the bank's experience in establishing legal regulations in banking operations; learned from the bank's experience in risk management. However, about the benefits of "taking advantage of the bank's large distribution network" there are some mixed opinions from some FT2s, in which they said that fintechs mainly rely on electronic connections, not dependent on distribution channels of the bank.

\subsection{The Obstacles Banks Face When Implementing the Cooperation}

Both SCB and CB banks said that obstacles may be encountered in the cooperation process, including breaching banks and customers information confidentiality. Particularly, SCB is interested in ensuring internal network security. Both SCB and CB banks believe that the legal system for fintech cooperation with banks has not yet completed and the legal procedures for cooperation are still complicated. However, there are two CB banks that have a neutral opinion on this issue. Factors related to the difference in organizational culture, the challenges of identifying the cooperation mechanism do not really have a clear opinion from banking experts on this subject.

The results of interviews with FT1 and FT2 regarding the obstacles when cooperating with banks shows that half of FT1 and FT2 believe their cultures are very much different compared with banks, the rest also say the difference is quite significant and suggest both sides need to understand each other's organizational culture and accept the difference. Only one FT2 is concerned about business secrets security, the remaining FTs say that they have very little concern on this matter. Most FT1 and FT2 think that they are relatively competitive in business scale compared to other FT competitors, therefore, they do not worry about the advantages of cooperating with the bank. Meanwhile, only one FT2 thinks their size is too small, hence, banks might not want to cooperate with them even though they have approached the bank several times. FT1 and FT2 all shared the same view that the legal system on cooperation was incomplete and complicated procedures caused great obstacles to the cooperation process.

\subsection{The Bank's Selection Criteria When Choosing Fintech Partners}

Interview results show that SCB and $\mathrm{CB}$ both consider Fintech's reputation, reputation and management experience as important criteria for banks to choose Fintech partners. Other criteria such as operating mechanism; financial capacity; Fintech's preeminent technology are also highly appreciated in order to increase customer satisfaction. In addition, 2 CBs said that they are more interested in benefits from cooperation (such as revenue / market share / innovation ...) rather than setting criteria for selecting partners.

\subsection{Their Strengths/ Weaknesses in the Cooperation Process}

The specific strengths of the bank compared to fintech include: an effective risk management mechanism (SCB and $\mathrm{CB}$ ); strict legal document system, large distribution channel; know your customer (KYC). However, regarding to "enhancing customer confidence"; a few banks (CB) believe that this is the strength of the bank, most banks have a neutral opinion on this issue. Half of the banks interviewed (SCB) said that "getting a better reputation and having strong customer network" are the bank's strengths when combined with Fintech, but CB banks have a neutral opinion on this issue.

The specific strengths of the bank compared to Fintech include: a well-designed risk management mechanism (SCB and $\mathrm{CB}$ ); as strict legal document system, modern technology infrastructure; The economies of scale; Large distribution channel; and understand the customers through KYC (Know-Your-Customer). However, in terms of "Enhancing customer confidence", only a few banks (CB) believe that this is the strength of the bank while most banks have a neutral opinion on this issue. Half of the banks interviewed (SCB) said "a good reputation and strong financial potential" are the bank's strength when combined with Fintech while CB banks have a neutral opinion on this issue.

When asked about the strengths of Fintech companies when combined with banks, most banks agreed on the outstanding strengths of Fintech which is strengths in data management and processing, as well as information technology development of Fintech companies. In addition, the companies also evaluate some other outstanding advantages such as acumen, innovation, Fintech services that help save money and time for customers as well as provide a wide variety of experiences for customers

\subsection{The Banking Products and Services from the Cooperation}

Areas of expert consultation include Electronic Payment Connection, Personal Financial Consulting, 
Peer-to-Peer Lending, Blockchain Technology Development, AI, Bigdata, Cloud Computing, Cyber Security and Automation process by robot. The results of the interview are as follows:

- Electronic payment connection: Interview results show that only 1 bank representative of SCB and 1 representative of $\mathrm{CB}$ said that they did not cooperate with Fintech, the rest of the banks have cooperated or intending to cooperate with Fintech company in this field.

- Personal financial advisory: Most representatives of SCB and CB banks said they were considering cooperating with Fintech in the field of personal financial advisory, only 1 CB said that they did not intend to cooperate. .

- Peer-to-peer lending: half of bank representatives (SCB and $\mathrm{CB}$ ) said they were considering cooperating with Fintech in the peer-to-peer lending sector, while the other half did not intend to cooperate with Fintech in this field.

- Blockchain technology development: The majority of bank representatives (SCB and CB) said that their bank is considering cooperating with Fintech companies in the development of Blockchain technology, only $1 \mathrm{CB}$ does not agree to form partnership with Fintech companies in this area.

- AI: Representatives from SCB and SB said they are considering cooperating with Fintech companies in AI application, in addition to this, a bank is currently cooperating with Fintech in this area.

Regarding other products such as Big Data mining, Cloud computing, Cyber security and robotic automation, the interview results showed that the two interviewed banks are currently cooperating with Fintech in In Big Data mining (SCB and $\mathrm{CB}$ ), 6 banks are considering cooperation (CB) and 2 banks will definitely cooperate with Fintech in this area (CB).

In general, the majority of banks see cooperation with Fintech companies in the above fields quite positive, especially in the field of AI applications, Big data mining, Network security and Robot automation process.

When interviewing fintech companies the stage in which the development of products applying new technologies such as AI, blockchain and robotics, the results showed that the Fintech companies questioned (FT1 and FT2) all say that they are in the product testing stage with a number of products has already been introduced to the market but not yet profitable. The remaining $20 \%$ (FT2) is only in the testing phase, without specific products.

\section{Conclusion and Policy Implications}

One of the bank's weaknesses is the lack of flexibility in the application of modern technology, leading to often high transaction costs and not timely meeting increasing customer needs. Meanwhile, Fintech has the advantage of innovation and the ability to apply technology flexibly and effectively, helping to reduce transaction costs and improve customer experience. However, one of the major challenges Fintech has to deal with is building customers' trust in security and safety, or a wide customer network. Analysis of the results of interviews with banking experts and Fintech companies shows that the trend of banking-Fintech cooperation benefits both sides, helping both parties take advantage of the strengths of their partners and overcome their weaknesses.

Specifically, Fintech benefits from joining the bank's cooperation include increasing brand recognition; reinforcing customer confidence; easy access to capital (for example, through the application of electronic wallets, receiving investment capital from the bank, etc); or utilizing the bank's experience in establishing legal regulations in the banking business as well as in risk management. Meanwhile, Fintech's preeminent technology to increase customer satisfaction and benefits from cooperation (revenue / market share / innovation, etc) are some of the important criteria for banks to consider a Fintech partner, thereby enhancing innovation and applying technology flexibly and effectively, reducing transaction costs and improving customer's experience.

Utilizing the partners' strengths is also the foundation for banks and Fintech to define a cooperation strategy in which each party has different priorities in the areas of cooperation. Specifically, the interview results show that the majority of banks view the cooperation with Fintech companies quite positively, especially in the fields related to high technology such as AI application, data mining, Big data, network security, or robotic automation. Besides, the areas that most of Fintech companies are interested in cooperating include electronic payment connection, Big data, data mining, cloud computing application; the remaining areas do not seem very attractive or suitable for cooperation (personal finance consulting, peer-to-peer lending, cybersecurity, robotic automation).

It can be seen that, although the trend of cooperation is positive with benefits for each party, the areas of interest to cooperation are not really diverse, mainly focusing on data mining technology applications. Meanwhile, the possibility of cooperation in the fields related to the provision of financial services products (except in the field of electronic payment connection) is quite limited. 
Interview results also give some comments on challenges and obstacles of the cooperation process. Specifically, the majority of banks and Fintech companies are concerned about customer information security, banking information security, internal network security, the incompleted legal requirements of cooperation as well as complicated legal procedures are among major obstacles of the cooperation process with Fintech companies. Some other factors hindering the cooperation process, including the differences in organizational culture as well as the ambigous cooperation mechanism, are issues that need attention and discussion between the two sides.

The cooperation between the banks and Fintech companies is considered a prerequisite for improving access to financial and banking services, bringing benefits to both parties and at the same time helping government authorities to manage the cooperation process more effectively. To meet the increasingly diversified needs and high expectations of customers, banks and Fintech need to continue promoting cooperation to provide more products and services. Banks and Fintech need to have an open mind to build appropriate business strategies towards beneficial cooperation, create strength for the service market, improve competitiveness of the economy. However, banks need to ensure that customers' data provided to Fintech companies need to be supervised closely and strict policies needed to be implemented to secure customer information. On the side of Fintech, customer information security must also be placed as priority. Ensuring information security is the basis for both parties to strengthen their reputation and trust with customers, as well as to expand the cooperation in diverse fields.

\section{References}

BNY Mellon. (2015). Innovation in payments: The future is FinTech. Retrieved from https://www.funds-europe.com/white-papers/bny-mellon/innovation-in-payments-the-future-is-fintech

Bodek, M. C., \& Matinjan, J. (2017). Innovation durch corporate incubation. In Innovationen und Innovationsmanagement in der Finanzbranche (pp. 117-144). Springer Gabler, Wiesbaden. https://doi.org/10.1007/978-3-658-15648-0_6

Bömer, M. (2020). Competitiveness of Fintech: An Investigation into Different Levels of Competitiveness Using Young Enterprises from the Financial Technology Industry (Doctoral dissertation, Heinrich Heine University Duesseldorf).

Bömer, M., \& Maxin, H. (2018). Why fintechs cooperate with banks-evidence from germany. Zeitschrift für die gesamte Versicherungswissenschaft, 107(4), 359-386. https://doi.org/10.1007/s12297-018-0421-6

Brock, H., \& Bieberstein, I. (2015). Multi-und Omnichannel-Management in Banken und Sparkassen. Wege in eine erfolgreiche Zukunft. Wiesbaden. https://doi.org/10.1007/978-3-658-06538-6

Bunea, D., Karakitsos, P., Merriman, N., \& Studener, W. (2016). Profit distribution and loss coverage rules for central banks. ECB Occasional Paper, (169).

Carson, D., Gilmore, A., Perry, C., \& Gronhaug, K. (2001). Qualitative Marketing Research. Sage, Publications, London. https://doi.org/10.4135/9781849209625

Child, J. (1974). Managerial and organizational factors associated with company performance part I. Journal of Management Studies, 11(3), 175-189. https://doi.org/10.1111/j.1467-6486.1974.tb00693.x

Chuen, D. L. K. (Ed.). (2015). Handbook of digital currency: Bitcoin, innovation, financial instruments, and big data. Academic Press.

Corea, F. (2015). What finance can learn from biopharma industry: A transfer of innovation models. Expert Journal of Finance, 3(1).

De Chernatony, L., \& Cottam, S. (2006). Internal brand factors driving successful financial services brands. European Journal of Marketing. https://doi.org/10.1108/03090560610657868

Deutsche Bank. (2014). Fintech-The digital (r) evolution in the financial sector. Deutsche Bank Research.

Di Rosa, A. (2020). Fintech Vietnam Market Map: Missing B2B Fintechs is a Chance for Swiss SMEs. Fintech News Singapore 2020.

Douglas, J. L., \& Grinberg, R. (2016). Old wine in new bottles: bank investments in FinTech companies. Rev. Banking \& Fin. L., 36, 667.

Dushnitsky, G., \& Lenox, M. J. (2006). When does corporate venture capital investment create firm value? Journal of Business Venturing, 21(6), 753-772. https://doi.org/10.1016/j.jbusvent.2005.04.012

Francis, E., Blumenstock, J., \& Robinson, J. (2017). Digital Credit: A Snapshot of the Current Landscape and Open Research Questions. 
Gans, J. S., \& Stern, S. (2003). The product market and the market for "ideas": Commercialization strategies for technology entrepreneurs. Research policy, 32(2), 333-350. https://doi.org/10.1016/S0048-7333(02)00103-8

Glaser, B., \& Strauss, A. (1967). The discovery of grounded theory Aldine Publishing Company. Hawthorne, New York.

Gulati, R. (1998). Alliances and networks. Strategic management journal, 19(4), 293-317. https://doi.org/10.1002/(SICI)1097-0266(199804)19:4<293::AID-SMJ982>3.0.CO;2-M

Haddad, C., \& Hornuf, L. (2016). The emergence of the global fintech market: Economic and technological determinants. Small Business Economics, 1-25. https://doi.org/10.2139/ssrn.2830124

Hellmann, T., \& Puri, M. (2002). Venture capital and the professionalization of start-up firms: Empirical evidence. The journal of finance, 57(1), 169-197. https://doi.org/10.1111/1540-6261.00419

Hill, C., \& Lynn, L. (2003). Producing human services Why do agencies collaborate? Public Management Review, 5(1), 63-81. https://doi.org/10.1080/1461667022000028861

Hornuf, L., Klus, M. F., Lohwasser, T. S., \& Schwienbacher, A. (2020). How do banks interact with fintech startups? Small Business Economics, 1-22. https://doi.org/10.1007/s11187-020-00359-3

Jakšič, M., \& Marinč, M. (2015). The future of banking: The role of information technology. Bančni vestnik, 68.

Jayawardhena, C., \& Foley, P. (2000). Changes in banking sector-The case of Internet banking in UK. Internet Research, 10, 19-31. https://doi.org/10.1108/10662240010312048

Kalmykova, Y., Rosado, L., \& Patrício, J. (2016). Resource consumption drivers and pathways to reduction: economy, policy and lifestyle impact on material flows at the national and urban scale. Journal of Cleaner Production, 132, 70-80. https://doi.org/10.1016/j.jclepro.2015.02.027

Keil, T. (2000). External corporate venturing: cognition, speed, and capability development. Helsinki: Helsinki University of Technology.

Košak, M., Li, S., Lončarski, I., \& Marinč, M. (2015). Quality of bank capital and bank lending behavior during the global financial crisis. International Review of Financial Analysis, 37, 168-183. https://doi.org/10.1016/j.irfa.2014.11.008

Lacasse, R. M., Lambert, B. A., Roy, N., Sylvain, J., \& Nadeau, F. (2016, April). A digital tsunami: FinTech and crowdfunding. In International Scientific Conference on Digital Intelligence (pp. 1-5).

Levinson, N. S., \& Asahi, M. (1995). Cross-national alliances and interorganizational learning. Organizational Dynamics, 24(2), 50-63. https://doi.org/10.1016/0090-2616(95)90071-3

Marous, J. (2016). Banking Trends Recap. MX. https://www.mx.com/moneysummit/jim-marous/

Maula, M. V. (2001). Corporate venture capital and the value-added for technology-based new firms. Helsinki University of Technology.

Meinert, M. C. (2017). Making friends with fintech. American Bankers Association. ABA Banking Journal, 109(5), 32.

Mocker, V., Bielli, S., \& Haley, C. (2015). Winning together a guide to successful corporate startup collaborations.

Nalebuff, B. J., Brandenburger, A., \& Maulana, A. (1996). Co-opetition. London: Harper Collins Business.

Navaretti, G. B., Calzolari, G., \& Pozzolo, A. F. (2017). FinTech and Banks: Friends or Foes? European Economy, (2), 9-30. https://doi.org/10.2139/ssrn.3099337

Ng, A. W., \& Kwok, B. K. (2017). Emergence of Fintech and cybersecurity in a global financial centre: Strategic approach by a regulator. Journal of Financial Regulation and Compliance, 25(4), 422-434. https://doi.org/10.1108/JFRC-01-2017-0013

Nielsen Vietnam. (2019). Global Findex, Statista, UNDATA. Hanoi Times.

Pavlou, P. A., \& Gefen, D. (2004). Building effective online marketplaces with institution-based trust. Information Systems Research, 15(1), 37-59. https://doi.org/10.1287/isre.1040.0015

Pavlou, P., Liang, H. G., \& Xue, Y. J. (2007). Understanding and Mitigating Uncertainty in Online Exchange Relationships: A Principal-Agent Perspective. MIS Quarterly, 31(1), 105-136. https://doi.org/10.2307/25148783 
Puschmann, T. (2017). Fintech. Business \& Information Systems Engineering, 59(1), 69-76. https://doi.org/10.1007/s12599-017-0464-6

PWC. (2016). How Fintech is shaping financial services. Global Fintech Report 2016. Retrieved from https://www.pwc.co.uk/financial-services/fintech/assets/FinTech-Global-Report2016.pdf

PWC. (2019). Crossing the line: How Fintech propelling FS and TMT firms out of their lanes. Global Fintech Report 2019. Retrieved from https://www.pwc.com/gx/en/industries/financial-services/assets/pwc-global-fintech-report-2019.pdf

Rotering, J. (1993). Zwischenbetriebliche Kooperation als alternative Organisationsform: ein transaktionskostentheoretischer Erklärungsansatz. Schäffer-Poeschel.

Salancik, G. R., \& Pfeffer, J. (1978). A social information processing approach to job attitudes and task design. Administrative Science Quarterly, 23(2), 224-253. https://doi.org/10.2307/2392563

Statebank. (2019). Vietnamese Statebank Report 2019.

Stuart, T. E., Hoang, H., \& Hybels, R. C. (1999). Interorganizational endorsements and the performance of entrepreneurial ventures. Administrative Science Quarterly, 44(2), 315-349. https://doi.org/10.2307/2666998

Thakor, A. V. (2020). Fintech and banking: What do we know? Journal of Financial Intermediation, 41, 100833. https://doi.org/10.1016/j.jfi.2019.100833

Thwaits, C. R. (2016). Unicorns and Fortresses: The barriers and enablers to effective fintech start-up collaboration with South African Banks (Doctoral dissertation). Gordon Institute of Business Science, University of Pretoria.

Tiberius, V., \& Rasche, C. (Eds.). (2017). FinTechs: Disruptive Geschäftsmodelle im Finanzsektor. Springer-Verlag. https://doi.org/10.1007/978-3-658-14187-5

Weber, B., \& Weber, C. (2007). Corporate venture capital as a means of radical innovation: Relational fit, social capital, and knowledge transfer. Journal of Engineering and Technology Management, 24(1-2), 11-35. https://doi.org/10.1016/j.jengtecman.2007.01.002

\section{Copyrights}

Copyright for this article is retained by the author(s), with first publication rights granted to the journal.

This is an open-access article distributed under the terms and conditions of the Creative Commons Attribution license (http://creativecommons.org/licenses/by/4.0/). 